\title{
Fisher-foragers Amidst the Reeds: Loptuq Perception of Waterscapes in the Lower Tarim Area
}

\author{
Ingvar Svanberg $^{1^{*}}$ and Sabira Ståhlberg ${ }^{1}$ \\ ${ }^{1}$ Institute for Russian and Eurasian Studies, Uppsala University, Uppsala, Sweden. \\ *ingvar.svanberg@ires.uu.se
}

\begin{abstract}
Toponyms and hydronyms encode important information about human perceptions of the environment in a specific context. This article discusses the Loptuq, a group of Turkic-speakers, who until the 1950s lived as fishers-foragers at the Lower Tarim River, Eastern Turkestan (contemporary Xinjiang, China), and their use of common reed (Phragmites australis) as an example for the close connection between language, culture, social relations, economic activities, and human perceptions about the surrounding environment. Operating in lakes and swamps for their economic activities (fishing, hunting, foraging, and occasional transport), exploring and observing vegetation and animal life, the Loptuq developed and transmitted information through naming their habitat. Today both their habitat and the earlier knowledge have disappeared, but the perceptions and uses of resources can at least partly be reconstructed through foreign explorers' narratives and field notes.
\end{abstract}

Received May 9, 2020

OPEN ठACCESS

Accepted August 31, 2020

DOI 10.14237/ebl.11.1.2020.1701

Published October 6, 2020

Keywords Cultural keystone species, Ecosystem services, Hydronyms, Local knowledge, Mental map, Toponyms

Copyright (c) 2020 by the author(s); licensee Society of Ethnobiology. This is an open-access article distributed under the terms of the Creative Commons Attribution-NonCommercial 4.0 International Public License (https://creativecommons.org/licenses/by-nc/4.0), which permits non-commercial use, distribution, and reproduction in any medium, provided the original author and source are credited.

\section{Introduction}

Toponyms, hydronyms, and animal and plant names are important sources for our understanding of human perceptions of and relations with the environment. They are often witnesses to societal, environmental, and even climatic change, as they constitute historical landmarks and records. Besides researching classification, naming, and the usefulness of different taxa, ethnobiologists also need to study human perceptions of the landscape to acquire deeper knowledge about the human-environment relationship and biota management (cf., Cunningham 2001; Nolan 2006; Johnson and Hunn 2011). The cultural and linguistic aspects of ecosystem services still remain a largely unexplored territory, and they extend far beyond toponyms. Vegetation and animal life are plentiful and varied, and so are the linguistic expressions referring to them (Millennium Ecosystem Assessment 2005). Linguistic materials never stand alone, and they should be analyzed together with their cultural, economic, and social contexts. Toponyms and other environmental namings are also subject to change over time. Mapping out knowledge and understanding, as well as linguistic reflections concerning the environment, becomes an even more complex process when we are dealing with a historical perspective, especially for cultures that have already disappeared (Ståhlberg and Svanberg 2017).

From the end of the 1870s to the beginning of the 1930s, around a dozen travelers to Central Asia mentioned the Loptuq, a small group of Turkicspeaking fisher-foragers in the Lower Tarim River area of Eastern Turkestan (now Xinjiang, China) in their publications (see Ståhlberg and Svanberg 2010, 2017). The Loptuq were previously unknown internationally, while local knowledge about them was mostly sketchy. Only a few traders and some Turki (now Uighur) oasis dwellers visited the Loptuq settlements. The Lop Nor (Lop Lake) region had been politically and culturally important until some 1,500 years earlier and then abandoned. In the nineteenth century, it was very sparsely inhabited, but the deserted ruins of ancient Loulan attracted international discoverers (see Hopkirk 1980). The socalled Great Game (expansion efforts of several 
states, chiefly Great Britain, Russia, and Qing China) in Central Asia brought political agents, spies, explorers, and adventurers into the region, but also travelers, who constructed their scientific fame upon the (re)discovery of historical sites buried for centuries in the desert sands.

Among the foreign visitors, only Sven Hedin (1865-1952) recurrently stayed with the Loptuq. Hedin studied the Lop Nor region carefully, meticulously recording hydronyms and toponyms during his mapping activities. Gathering plants, he was able to at least partly identify the local toponyms based on plant names. During his first expedition in 1896, Hedin explored the Lower Tarim River region, lived in Loptuq reed huts, and "spoke their own language, eating the food they ate, and was almost as poor as themselves" (Hedin 1898b:898). During his next expedition in 1899-1902, he stayed with the Loptuq for more than a year (Hedin 1904, 1906). Hedin made a third and last visit to them in 1933 (Hedin 1940). Hedin's materials have until now rarely been utilized for ethnobiological research, but they yield important information (Hällzon et al. 2019; Ståhlberg and Svanberg 2010).

\section{Aim, Sources, and Methods}

This study discusses the relations between toponyms and human perceptions of the environment with an example from a less known ecological setting, the waterscape. Waterscapes and marshes are seldom understood. In many areas of the world, they are classified as wastelands and often systematically deconstructed, as more attractive or profitable use of the areas are preferred, or for political reasons (cf., Rendón et al. 2019). We examine Loptuq perceptions of their waterscape environment through naming and use of reed, highlighting through this example the importance of linguistic materials in ethnobiology for understanding local knowledge in a historical context.

Common reed (Phragmites australis) was a significant resource for the Loptuq. The reed belts provided many and varied ecosystem services, including provisional (e.g., food, energy, raw materials, and ornamental), regulating (habitat for food, fish, and birds), and cultural (language expressions, toponyms, and mental maps). Reed use exists in several other areas of the world (e.g., Köbbing et al. 2014; Prigarin 2015; Storå 1985), but the Loptuq utilization has not been previously studied._We have chosen samples of reed-related toponyms, as they are abundant reflect how the Loptuq perceived their main ecological settings and identify important locations for economic activities and the transmission of knowledge and social relations. Our study is an effort to reconstruct and thus preserve, at least in some aspects, a way of life that is now lost.

For the Loptuq, like for many other small groups in Central Asia, documentation is highly deficient or one-sided, which makes the piecing together of scraps of information into a serious challenge for the scientist; yet it is not an impossible task, which our study illustrates. Among the foreign and local visitors to the Loptuq, only one, Sven Hedin, had an interest in documenting the Loptuq's view of their surroundings (cf., Jarring 1997). He was also sufficiently competent linguistically and scientifically, and his extensive field notes contain thousands of toponyms and hydronyms, as well as notes on their meanings, which include data on fauna, plant-life, trapping, fishing methods, and dwellings. These notes are mainly found in his diaries, which have been systematically analyzed and published by the Turkologist Gunnar Jarring (1997). We have also used the published works of Hedin, which provide detailed descriptions of the landscape and human activities in the Lop marshes and reed belts (Hedin 1898a, 1900, 1904, 1906). Other travel reports are considered when relevant; the narratives and scientific reports by Nikolay Przewalsky, Mikhail Pevtsov, Gabriel Bonvalot, Fernand Grenard, Ellsworth Huntington, Albert von Le Coq, Aurel Stein, and Sergei Malov, have been used in our earlier studies on the Loptuq (Hällzon et al. 2019; Ståhlberg and Svanberg 2010, 2017).

The methods used in this article are ethnobiological and ethnohistorical. Western science-based societies have been criticized for simplifying ecosystems in order to manage them. Local knowledge also tends to be simplified or largely ignored (Peloquin and Berkes 2009). Cultural, social, and economic activities are, however, closely connected with language, perceptions of the environment, and the use of resources. Therefore, the different aspects must be analyzed together. Further, in the case of the Loptuq, the concept of traditional ecological or environmental knowledge is problematic. We cannot assert that there was a tradition, or the concept needs to be revised. The sources cover only about fifty years in the life of a highly adaptive group. Following alternating river waters and lakes in the desert, the Loptuq had to change and assimilate new 


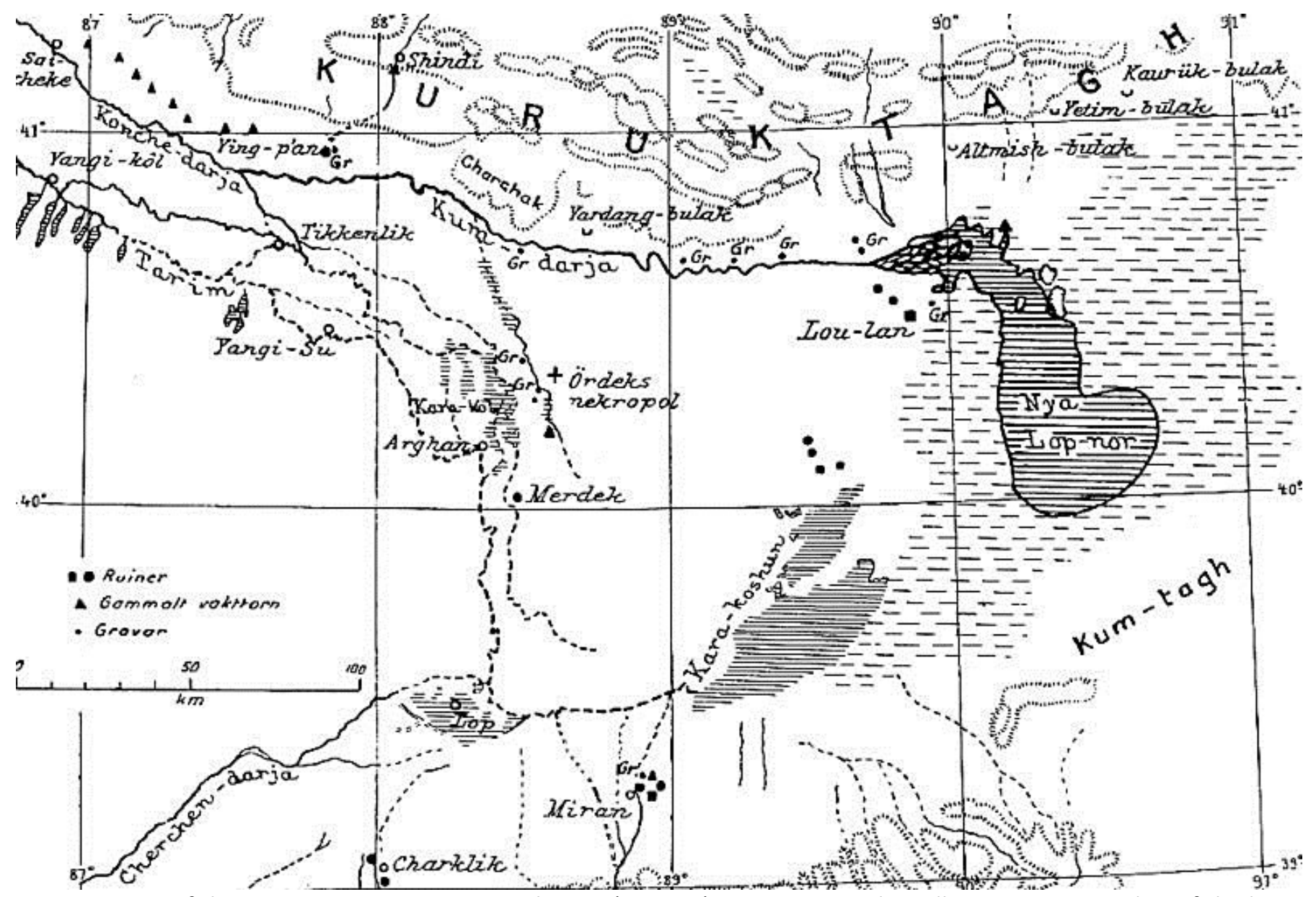

Figure 1 Map of the Lop Nor region, Eastern Turkestan (Xinjiang). Drawing 1933 by Folke Bergman, member of the last expedition organized by Sven Hedin. Legend: Ruiner = ruins; Gammalt vakttorn = old watch-tower; Gravar = graves; Bulak = well; Ördeks nekropol = Ördek's necropolis; Nya Lop-nor = New Lop Nor (actually the position of the lake from 1921 to 1971). Source: Sven Hedin Foundation, Stockholm (from Bergman 1935).

data faster than, for instance, oasis farmers. Their environmental knowledge and use of resources changed during the short-documented period, partly due to ecological changes and partly due to increasing contact with the outside world, mainly traders, a dozen foreign travelers, and increasing state control. With the changes in habitat and subsequently also local knowledge, we can suppose that the perceptions about the environment underwent modifications, but to what degree and how remains an open question.

\section{Geography and Population}

The Tarim River is an endorheic river, almost 2,000 kilometers long, flowing eastward through the Taklamakan Desert in Eastern Turkestan. Nikolay Przewalsky was the first foreign explorer to visit the lower reaches of the river in 1876-1877. He found a terminate lake known as Kara Koshun filled with fresh and brackish water. Fishermen living in reed huts and using dugout canoes for fishing and transport inhabited the shores of this considerable lake (Przewalsky 1878).

Loptuq ('Lop people'), exonym Loplik, was a small linguistically and culturally distinct group of Turkicspeakers (for their origins, history, and administration, see Ståhlberg and Svanberg 2017). They lived in a remote region between the Taklamakan and Kumtag Deserts with few contacts to the outside world, except seasonal visits by itinerant traders and some exchange with their Turki neighbors. The Loptuq subsisted on fishing, hunting, and gathering in contrast to the oasis farmers, and they transported occasional traders and foreign travelers with their canoes (Ståhlberg and Svanberg 2010, 2017). The tendency toward seclusion, especially from Turki farmers, was mainly due to a 
fear of contagious diseases, but the Loptuq also avoided the oases because Turki feudal lords exploited them as workforce in the fields (Hoppe 2006; Svanberg 1987).

By the 1880s, the quantity of animals and fish had begun to decline in the Lop Nor region (Figure 1). Several Loptuq moved to oases settlements, changing their subsistence to agriculture and animal-breeding. Droughts in Central Asia have been on the increase since the mid-1800s (Pevtsov 1895). The process of salination and expansion of the deserts also continues today (Ståhlberg 2004). In the early twentieth century, the Tarim River changed its course and caused the terminal lake to alter its location between the Lop Nor dried basin, the Kara Koshun dried basin, and the Taitema Lake basin. The shifts caused an international debate among scholars as to the exact location of the terminal lake. In 1921, due to human intervention, the lake shifted its position to the Lop Nor basin (Hörner and Chen 1935). The ecological conditions discussed in this article were present before the last change took place.

Today, the previous Loptuq habitat has been destroyed. The enormous Chinese immigration to Xinjiang since the 1950s increased the need for arable land and irrigation, and the waters of the Tarim River were deflected from its course (Mischke et al. 2020; Zhang 2006). Plant and animal life decreased critically or disappeared. The People's Republic of China used the Lop Nor dried basin for nuclear tests until the end of the 1990s, and it is not suitable for human settlement anymore (Ståhlberg and Svanberg 2017; Hällzon et al. 2019). The descendants of the previously river- and lake-dwelling groups have been displaced in villages and in the oasis towns of Miran (Chinese: Milan) and Charklik (Ruoqiang) at the southern rim of the Taklamakan Desert, far from their original habitat (Hoppe 2006). A few remnants of Loptuq culture still exists in their music, but lifestyle, traditions, and language have been replaced by Uighur just within a couple of generations (Abdurehim 2014; Trébinjac 2017). Loptuq language and culture should be considered critically endangered, if not already extinct (Abdurehim 2016; Hällzon et al. 2019).

\section{Waterscape Subsistence}

The climate of the Lower Tarim River area was harsh around a century ago with a mean January temperature of $-10^{\circ} \mathrm{C}$ and July average temperatures of $+28^{\circ}-+30^{\circ} \mathrm{C}$. Rain and snow were very rare and farming was almost impossible due to salt in the soil (Ståhlberg and Svanberg 2010; see also Ståhlberg 2004). Sandstorms, buran, occurred regularly, sometimes lasting for weeks. During winter and spring, icy winds from the north and north-west swept the area (Hedin 1898b; Meserve 1992; Pevtsov 1895). During the three winter months (January to March), this wind could reach a strength of ten on a ten-grade scale. The Loptuq called it qara buran 'black storm', since it "carried atmospheric particles, which darkened the sky and caused dusk to appear at midday" (Hedin 1896:503). During other seasons the atmosphere was comparatively calm, and the winds were weak and of short duration (Hedin 1896).

In 1877, the Loptuq lived mainly on fishing and foraging (Przewalsky 1878). Their mode of subsistence depended on the lake and river habitat, and the changing water conditions. The Loptuq mostly fished, but also trapped waterfowl with snares and consumed the meat either fresh or preserved. They gathered common reed, locally called qamïs, for huts, fuel, and furniture. The clothes and nets were manufactured by the fibers of the Lop hemp (čege, rige; Apocynum pictum) gathered in spring and fall along the riverbanks (Pevtsov 1895; Przewalsky 1878). When Sven Hedin visited in the 1890s, the Loptuq still mainly fished, hunted ducks, gathered ducks' eggs, and foraged reed shots for food. Some households had taken up shepherding due to the changing environmental conditions, including the falling river and lake water levels (Hedin 1898b).

Few plant species were available in the Loptuq habitat (for details on their plant knowledge, see Hällzon et al. 2019). Common reed and Lop hemp might be regarded as cultural keystone species (Platten and Henfrey 2009). Cigelik 'Apocynum-region', Cigelik quduq 'Apocynum well', and other similar toponyms indicated where Lop hemp grew (Jarring 1997). A fairly common plant was also Southern cattail (Typha domingensis) locally called jäkän (Przewalsky 1878). Hedin observed that the villagers of Tikenlik ('Thistle place') subsisted on fish, wild duck meat, duck and goose eggs, and the stalks and sprouts of jäkän. Many places were known as Jäkänlik 'Cattail place', for instance Jäkënlik-köl ('Cattail Lake') (Hedin 1904). There was at least one Turqomaqtiq köl 'Sedge lake' (Hedin 1906; Malov 1956; cf., Hällzon et al. 2019). A couple of tamarisk species, locally known as july un (Tamarix spp.), played an important role for simple craft, which is indicated by several place names 
(Jarring 1997). Berries of the wild oleaster tree (Elaeagnus angustifolia) were harvested by the Loptuq as food (Hedin 1904; Katanov and Menges 1933).

The Tarim River and its lakes were rich in fish, with several native species (Walker and Yang 1999). Mikhail Pevtsov (1895) recorded around 1890 that the Loptuq distinguished between five economic important species of fish: Balkhash marinka (Schizothorax argentatus [locally known as eger baliq 'saddle fish']); Tarim schizothoracin (Schizothorax biddulphi [ottur baliq]); Kashgarian loach (Hedinichthys yarkandensis [tezck baliq 'dung fish']); Scaly osman (Diptychus maculatus [it baliq 'dog fish']); and Big-head schizothoracin (Aspiorbynchus laticeps [minlai beliq]). A couple of other, not yet identified fish species are mentioned by a few other travelers (Hällzon et al. 2019; Jarring 1998). Hedin (Jarring 1997) and Malov (1956) mentioned laqu as a fish with big head, the biggest kind of fish in the lakes. It might be the same as minlai (probably a Chinese loanword; mianli) for Aspiorbynchus laticeps (Hällzon et al. 2019). A few other fish names have been recorded, but they still evade the possibility to be identified scientifically. Contemporary Loptuq descendants do not know them, and at present newly introduced, often invasive, species have replaced them (Walker and Yang 1999).

Fishing activities were reflected in many ways in the waterscape toponyms. The Loptuq regularly placed fish traps, mandzar, in the reed belts J Jarring 1997). The fish traps were fastened to two poles stuck onto the bottom of the canal (Hedin 1904). A mandzar baši 'fish trap head or top' was the uppermost place in the channel for setting the fish trap (Hedin 1904). The fish they caught found their way into toponyms, for instance Tinacinï kötörmesü 'Portage of the tini fish' (Hedin 1904), Laquluq köl 'Lake of the laqu fish', Semilaqu köl 'Lake of the fat fish', and JuY an-baliq köl 'Lake where big fish are found' (Hedin 1904, 1906; Jarring 1997; Malov 1956). The waterscape also attracted mosquitoes. A place known for the abundance of mosquitoes, kümüt (Malov 1956), was known as Kumutluk (Hedin 1904).

Fishing took place from early spring to late fall. The spawning-season was in May, when the fish swam down the river to the lakes. During this month, the Loptuq had their most active season. They set nets and traps in the lakes and from their dugout canoes. The canoes, kemi, were skillfully maneuvered by men as well as women standing upright and driving the fish into the nets. The greater part of the fish captured during the spring was dried in the sun for winter storage. After cleaning and removing the entrails, the fish were dried unsalted. The stock fish were stored indoors in reed huts (Hedin 1900; Pevtsov 1895).

The canoes varied very much in size: the largest Hedin (1898b) observed was over eight meters long and $3 / 4$ meter broad. His own canoe was about six meters long, but hardly more than half a meter across. Three men, "working hard", were able to hew a kemi out of a fresh poplar trunk (toghrak; Populus euphratica) in five days. The tree had to be sound at heart and free from cracks. The Loptuq never used sails, but always paddled, using an oar with a thin, broad blade. They called their oar gädzaq, "which they ply with great strength and dexterity" (Hedin 1898b:890). For transport of people and freights, they used large canoes and double canoes, qoš kemi (Jarring 1997).

The waterscape and especially the reed belts were not only a habitat for fish, but also for different kinds of mussels, snakes, crabs, and several kinds of fowl. On dry land, wild boar, wolves, foxes, weasels, and hares roamed. The Caspian tiger (Panthera tigris tigris), is now extinct, but it appeared sometimes in the reed belts and was hunted mainly for fur (Hedin 1898b; Pevtsov 1895; Przewalsky 1878). In the Lower Tarim River area, one place was called Jolbarš äsildi 'where the tiger was killed' (Jarring 1997). Itinerant Chinese traders were willing to pay a high price for tiger meat, a costly ingredient in traditional Chinese medicine, and the Loptuq hunted or poisoned the animals and sold the meat (Le Coq 1928).

\section{Reed Resources, Utilization, and Management}

The Loptuq fished and hunted in the reed belts, along the riverbanks and in the marshlands of the smaller lakes in the waterscape. Common reed, an aquatic gramineous perennial, was abundant in the habitat and of crucial importance for subsistence. A belt of gigantic reed, "each fully 25 feet [7.6 meters] in height and measuring $2-1 / 4$ inches $[5-0.6 \mathrm{~cm}]$ in circumference at the surface of the water, stretched diagonally across the lake," Hedin (1898b:898) noted. Reed provided invaluable services to the Loptuq. The plant not only supplied them with construction materials and fuel, but the young sprouts were used as food. In fall, panicles were gathered for making beds. In summer, fresh panicles were harvested to produce a tough, viscous mass used as sugar (Przewalsky 1878). Reed were also a part of Loptuq rituals. Corpses were placed on a stretcher made of reeds and osiers, and 
the corpses were covered with more reeds at burial. In some cases, graves were covered with sand rather than reed (Bonvalot 1891; Hedin 1900).

The Loptuq lived in permanent or semipermanent hamlets comprising 10-20 households, spread out along the riverbanks. The most prevalent type of dwelling was the qamis $u j$ 'reed hut'. It was constructed on a rough framework of poplar logs tied together. The logs in the corner were called tuluk, the roof beams baraj, while smaller joints were called cäsijagač. On the log framework, bundles of reed were tied in a vertical position. The flat roof was also made of reed and the ground inside the hut was covered with reeds. In the middle of the floor, there was a fireplace. The reed houses consisted of several rooms; some were used mainly for storing stockfish and smoked duck. Reed also provided fuel (Hedin 1900; Littledale 1894; Przewalsky 1878). A more modest hut for fishermen and shepherds was the satma, built of poles, boughs, brushwood, and bundles or reed (Hedin 1898b, 1940; Przewalsky 1878).

The Loptuq managed the reed belts to improve their economic activities in several ways. One of the most important methods was the creation and maintenance of channels in the thickets for fishing and transport. Hedin (1898b:908) observed:

Were it not for the narrow channels which the Lop men keep open, these forests of reed would be absolutely impassable; even the channels (capyan) would grow over in one year, if the young sprouting reeds were not pulled up by the roots in spring. As a rule a capy an is about a yard wide, and it is lined on both sides by reeds as hard and impassable as boarded walls, not less than fifteen or sixteen feet [more than 4.5 meters] high. In several places the reeds are tied together in standing sheaves, or bent back, so as not to fall forward and choke up the lode or channel.

Every channel would at some point open into a round water basin with half a dozen lagoons. When the canoe appeared in the open space, "the boatmen dipped in their oars and made her skim across the open pool like wild duck, so that the water hissed off her bow, and I could not help fancying that in a minute or so we should dash our heads against a wooden wall", Hedin (1898b:909) described his experience (cf., Pevtsov 1895). However, the reeds bent apart "like curtains," and the canoe glided unharmed into the next narrow tunnel. The primary object of these channels, which intersected each other in every direction and created "a labyrinth maze", in which a stranger would "infallibly be lost", was not transport. They were used for catching fish. Hedin (1898b:909) noted: "We rowed over hundreds and hundreds of nets, and in the clear transparent water underneath I could see countless shoals of fish. We caught a few as we went along, and cooked them." Each family had its own fishing channel, in which members alone were entitled to set their nets (Hedin 1898b); this was probably a measure to avoid conflicts and overfishing.

The Loptuq used the same vessels both in the reed belts and on open water. Hedin (1898a:257) wrote that the Loptuq

spend half of their lives in their long, narrow canoes. ... Noiseless and swift as fishes, the light canoes glide over the dark blue bosom of the lake, with its reed-hidden shores and its playfully curling eddies.

For transport they used larger canoes. A tiny canoe could get through the channels easily, but bigger and heavier boats had to slowly work their way through. Out on the open lake, the rowers generally knelt down, but among the thick reeds, they stood up to see better, punting the canoe along. As a rule, there were two oarsmen. The one in the rear usually stood upright to be able to see over the head of the one in front (Hedin 1898b).

For the Loptuq, who had learned since childhood to navigate and move in the thickets, the reed "forests" provided no obstacle. When the channel became too narrow, the boatmen laid down their oars and forced the boat onward with their arms, using the reeds as a prop. For a stranger not accustomed to this kind of waterscape, the experience could be disturbing. Hedin (1898b:910) confessed

We were completely shut in on all sides. Not a drop of water was visible; it was entirely hidden by the reeds and the boat. Into that dark, close, hot tunnel, not a gleam of sunshine penetrated. I drew a sigh of intense relief when we at length emerged from the watery defile and emerged upon the last open lake, with its surface crumpled by the breeze.

Most explorers were puzzled about how the Loptuq found their way through the labyrinths of channels (see for instance Hedin 1898b). Ellsworth Huntington (1907:246) supposed hat 
perhaps their ability originates from the necessity of keeping in mind the exact length and direction of the multitudinous and intricate canals and little lakes of the reedy swamp", Possibly the locations of the channels and lagoons, combined with regular navigation and management of the channels helped the Loptuq to create a detailed mental map of their specific reed belt.

Reed played a crucial role in the cognitive reality of the Loptuq, and this is reflected in the many toponyms where reed, qamiš, is a component, such as Qamïs algan köl 'Lake where reed was fetched' and Qamišluq bulaq 'Reed spring' (Jarring 1997). Many of the channels or canals were named after the owner or person connected with them, setting down social rules and fishing and utilization rights, but also responsibility for taking care of it. Hedin recorded more than thirty personalized channel names (Jarring 1997). Abdal čapyan indicated 'Abdal's canal', Gadaj rapy an 'Gadaj's canal', and Istam čapy an 'Istam's canal'. Some channels were named after events that had occurred there or according their shape or condition, such as Qum čapy an 'Sandy channel' or Con čapy an 'Big channel' (Jarring 1997). A passage for carrying canoes over land was known as kötörma, and such places were named for instance Usay kötörma 'Wide portage', but also according to a person, Abass kötörmesu 'Abas' place for carrying canoes' (Hedin 1904).

\section{Conclusions}

The naming of the waterscape environment helped the Loptuq to pinpoint, describe, and transmit information. The toponyms can today be seen as a history book and mental map of the Lop Nor area at the end of the nineteenth and beginning of the twentieth century, seen through the eyes of the local inhabitants, the Loptuq. Important ecological, economic, and social information, crucial for a fishing -hunting-foraging culture subsisting on a waterscape, were embedded in the toponyms and hydronyms and other expressions for the environment. The abundance of different reed-related names reflected the importance of reed in Loptuq everyday life, culture, collective memory, and understanding and perception of their surroundings.

Ecological names form the majority, reflecting for instance the abundance of plants or mosquitoes, or the outward aspect of a place. The economic aspect was reflected in among others fish-based hydronyms. Social information was supplied by personal names, which indicated who had the right to fish or use resources, such as reed, from a specific spot, but they also indicated who was responsible for taking care, managing, and keeping a channel open for canoe traffic. Channels belonged to a person or a family, but everybody could use them for transport and moving through the reed belt. Experience-based toponyms, such as the place where a tiger had been killed, are the least frequent names, but they open up an interesting view into Loptuq perceptions. Tigers were usually poisoned; a place noted for tiger killing means probably that someone (or several hunters) had met and killed a living tiger there, a dangerous feat to remember. Possibly the name was also given as a warning that this was a locality tigers might roam in.

Sven Hedin recorded thousands of toponyms, but there were certainly many more, which changed over time and place. We can and should also assume that both the local knowledge and the linguistic reflections of environmental understanding was in a constant process of change among the Loptuq, who moved with the shifting waters. Today, these once concrete markers are gone and survive only in old maps and travel narratives. The Loptuq traditional culture and knowledge, as well as the language have since changed, but the sources can still tell us something about the Lop Nor waterscape and the perceptions the Loptuq created about it. The example of the Loptuq shows that the concept of traditional knowledge is problematic when analyzing a highly adaptable group. Linguistic materials cannot be divided from their cultural, economic, and social contexts, but must be analyzed from a holistic perspective, which applies also for ethnobiological data. Our knowledge can never be complete, but we can at least to some extent reconstruct different kinds of perceptions, even from already extinct cultures and on the basis of very limited sources, to enrich our understanding about human survival and subsistence in challenging environments.

\section{Declarations}

Permissions: None declared.

Sources of funding: None declared.

Conflicts of Interest: None declared.

\section{References Cited}

Abdurehim, E. 2014. The Lopnor Dialect of Uyghur: A Descriptive Analysis. University of Helsinki, Helsinki, Finland. 
Abdurehim, E. 2016. An Endangered Turkic Variety in China: The Lopnor Dialect of Uyghur. In Endangered Turkic Languages, III: Interdisciplinary Approaches, edited by S. Eker and Ü. Ç. Şavk, pp. 357-370. International Turkic Academy, Ankara, Turkey.

Bergman, F. 1935. Newly Discovered Graves in the Lop-Nor Desert. In Hyllningsskrift Tillägnad Sven Hedin på Hans 70-Arsdag, den 19 Febr. 1935, edited by J. Charpentier, pp. 44-61. Svenska Sällskapet för Antropologi och Geografi, Stockholm.

Bonvalot, G. 1891. Across Thibet, vol. 1. Cassell, London.

Cunningham, A. 2001. Applied Ethnobotany: People, Wild Plant Use and Conservation. Earthscan Publication, London.

Hällzon, P., S. Ståhlberg, and I. Svanberg. 2019. Glimpses of Loptuq Folk Botany: Phytonyms and Plant Knowledge in Sven Hedin's Herbarium Notes from the Lower Tarim River Area as a Source for Ethnobotanical Research. Studia Orientalia Electronica 7:96-119. DOI:10.23993/store.76475.

Hedin, S. 1896. Lop-Nor-Bäckenets Vandring. Geologiska Föreningen i Stockholm Förhandlingar 18:499_ 514. DOI:10.1080/11035899609445463.

Hedin, S. 1898a. Four Years' Travel in Central Asia. The Geographical Journal 11:240-259. DOI:10.2307/1774678.

Hedin, S. 1898b. Through Asia, vol. 2. Methuen and Co., London.

Hedin, S. 1900. Die Geographisch-wissenschaftlichen ergebnisse meiner Reisen in Zentralasien, 1894-1897 (Ergänzungsheft Nr. 131 zu A. Petermanns Mitteilungen). Justus Perthes, Gotha, Germany.

Hedin, S. 1904. Scientific Results of a Joumey in Central Asia, 1899-1902, vol. 1. The Tarim River. Lithographic Institute of the General Staff of the Swedish Army, Stockholm.

Hedin, S. 1906. Scientific Results of a Joumey in Central Asia, 1899-1902, vol. 2. Lop-Nor. Lithographic Institute of the General Staff of the Swedish Army, Stockholm.

Hedin, S. 1940. The Wandering Lake. George Routledge and Sons, London.
Hopkirk, P. 1980. Foreign Devils on the Silk Road: The Search for the Lost Cities and Treasures of Chinese Central Asia. John Mayer, London.

Hoppe, T. 2006. The Lopliks, Their Environment and Ecological Restauration. In Watershed and Floodplain Management along the Tarim River in China's Arid Northwest, edited by T. Hoppe, B. Kleinschmit, B. Roberts, N. Thevs and Ü. Halik, pp. 221-236. Shaker, Aachen, Germany.

Hörner, N., and P. C. Chen. 1935. Alternating Lakes: Some River Changes and Lake Displacements in Central Asia. In Hyllningsskrift Tillägnad Sven Hedin på Hans 70-Arsdag den 19 Febr. 1935, edited by J. Charpentier, pp. 145-166. Svenska Sällskapet för Antropologi och Geografi, Stockholm, Sweden.

Huntington, E. 1907. The Pulse of Asia: A Journey in Central Asia Illustrating the Geographic Basis of History. Houghton Miflin, Boston.

Jarring, G. 1997. Central Asian Turkic Place-Names. Lop Nor and Tarim Area. An Attempt at Classification and Explanation Based on Sven Hedin's Diaries and Published Works. Sven Hedin Foundation, Stockholm.

Jarring, G. 1998. Agriculture and Horticulture in Central Asia in the Early Years of the Twentieth Century with an Excursus on Fishing. Royal Society of Letters in Lund, Lund, Sweden.

Johnson, L. M., and E. Hunn. 2011. Introduction. In Landscape Ethnoecology: Concepts of Biotic and Physical Space, edited by L. M. Johnson and E. Hunn, pp. 111. Berghahn Books, New York.

Katanov, T. T., and K. H. Menges. 1933. Volkskundliche Texte aus Ost-Türkistan. Verlag der Akademie der Wissenschaften, Berlin.

Köbbing, J. F., N. Thevs, and S. Zerbe. 2014. The Utilisation of Reed (Phragmites australis): A Review. Mires and Peats 13:1-14.

Le Coq, A. von. 1928. Von Land und Leuten in Ostturkistan. Verlag der J. C. Hinrichs'schen Buchhandlung, Leipzig, Germany.

Littledale, G. R. 1894. A Journey across Central Asia. The Geographical Journal 3:445-472.

Malov, S. E. 1956. Мобнорский Язык. Изслательство АН Киргизской ССР, Фрунзе [Lobnor Language. Kirghiz SSR Academy of Sciences, Frunze, Kirghiz SSR]. 
Meserve, R. I. 1992. A Natural Calamity in Inner Asia: The Buran. Ural-altaische Jahrbücher 64:105-116.

Mischke, S., C. Liu, and J. Zhang. 2020. Lop Nur in NW China: Its Natural State, and a Long History of Human Impact. In Large Asian Lakes in a Changing World, edited by S. Mischke, pp. 207-234. Springer Water, Cham, Switzerland. DOI:10.1007/978-3-030 -42254-7_7.

Millennium Ecosystem Assessment 2005. Ecosystems and Human Well-being: Synthesis. Island Press, Washington DC.

Nolan, J. M. 2006. Ethnoecology. In The Encyclopedia of Anthropology, edited by James Brix, pp. 846-848. Sage Publications, New York.

Peloquin, C., and F. Berkes. 2009. Local Knowledge, Subsistence Harvests, and Social-Ecological Complexity in James Bay. Human Ecology 37:533545. DOI:10.1007/s10745-009-9255-0.

Pevtsov, M. V. 1895. Труды Тибетской Экспедиции 1889-1890 гг 1. Путешествие по Восточному Туркестану, Кунь-Ауню, северной окраине Тибетского нагорья и Чжунгарии в 1889-м и 1890-м годах. Тип. М.М. Стасюлевича, СанктПетербург [Proceedings of the Tibetan Expedition in 1889-1890. Part 1. Travel to East Turkestan, Kun-Lun, the Northern Edge of the Tibetan Plateau and Dzhungaria in 1889-1890. M. M. Stasyulevich, Saint Petersburg, Russia].

Platten, S., and T. Henfrey, 2009. The Cultural Keystone Concept: Insights from Ecological Anthropology. Human Ecology 37:491-500. DOI:10.1007/s10745-009-9237-2.

Prigarin, A. 2015. Fishing Traditions among Old Believers in the Danube Delta: Survival Strategies in the 19th Century. In Biopolitics of the Danube Delta: Nature, History, Policies, edited by C. Iordachi and K. van Assche, pp. 223-242. Lanham, Lexington, KY.

Przewalsky, N. M. 1878. Reise des Russischen Generalstabs -Obersten N. M. Przewalsky von Kuldscha über den ThianSchan an den Lob-Nor und Altyn-Tag 1876 und 1877. (Ergänzungsheft Nr. 58 zu A. Petermanns Mitteilungen). Justus Perthes, Gotha, Germany.
Rendón, O. R., A. Garbutt, M. Skov, I. Möller, M. Alexander, R. Ballinger, K. Wyles, G. Smith, E. McKinley, J. Griffin, M. Thomas, K. Davidson, J. F. Pagès, S. Read, and N. Beaumont. 2019. A Framework Linking Ecosystem Services and Human Well-Being: Saltmarsh as a Case Study. People and Nature 1:486-496. DOI:10.1002/ pan3.10050.

Storå, N. 1985. Adaptive Dynamics and Island Life. Resource Use in the Åland Islands. Studia fennica 30:113-144.

Ståhlberg, S. 2004. Salt of Life, Salt of Death. Salination of Deserts in Central Asia and China. In Tuz Kitabi, edited by E. Gürsoy Naskali and M. Sen, pp. 9-14. Kitabevi, Istanbul, Turkey.

Ståhlberg, S., and I. Svanberg. 2010. Loplyk Fishermen: Ecological Adaptation in the Taklamakan Desert. Anthropos 105:1-17. DOI:10.5771/0257-9774-2010-2-423.

Ståhlberg, S., and I. Svanberg. 2017: When is a Foraging Society? The Loplik in the Tarim Basin. In Hunter-Gatherers in a Changing World, edited by V. Reyey-Garcia and A. Pyhälä, pp. 20-40. Springer, Cham, Switzerland.

Svanberg, I. 1987. The Loplyks: A Vanishing Fishing and Gathering Culture in Xinjiang. Meddelanden. Svenska Forskningsinstitutet $i$ Istanbul 12:57-81.

Trébinjac, S. 2017. Le Retour des Sauvages Poilus de Dzoungarie: Réflexions d'une Ethnographe au Sujet des Loplik (Xinjiang, R.P.C.). Études Orientales 2016:227-290.

Walker K. F., and H. Z Yang. 1999. Fish and Fisheries in Western China. In Fish and Fisheries at Higher Altitudes: Asia, edited by T. Petr, pp. 237-278. FAO Fisheries Technical Paper 385. FAO, Roma, Italy.

Zhang, L. 2006. A Historical Review of the Changes to the Course of the Lower Tarim River. In Watershed and Floodplain Management Along the Tarim River in China's Arid Northwest, edited by T. Hoppe, B. Kleinschmit, B. Roberts, N. Thevs, and Ü. Halik, pp. 167-177. Shaker, Aachen, Germany. 